\title{
CLINICAL STUDY OF CUTANEOUS MANIFESTATION OF GERIATRIC AGE GROUP
}

\author{
Sharath Kumar B. C1, Kavya Raju Nayak ${ }^{2}$
}

1 Professor and HOD, Department of Dermatology, KIMS, Bangalore.

${ }^{2}$ Consultant Dermatologist, Department of Dermatology, Kaya Skin Clinic and Apollo Clinic, HSR Layout.

\section{ABSTRACT}

\begin{abstract}
BACKGROUND
Due to the degenerative and metabolic changes occurring throughout the skin layers during the aging process, elderly people are vulnerable to a wide variety of dermatological conditions. The population is getting older with a greater percentage of population over 60 years. Hence, an increased emphasis on geriatric medicine is inevitable. Geriatric dermatology is a speciality, which requires special attention. With this background, the present study was undertaken. To describe the clinical pattern and epidemiological profile of cutaneous manifestation in elderly. To assess the relationship between the cutaneous findings and systemic diseases in elderly.
\end{abstract}

\section{MATERIALS AND METHODS}

This is a descriptive study done on a total of 200 patients aged above 60 years attending the OPD and IPD of Kempegowda Institute of Medical Sciences Hospital between June 2012 and November 2012. A detailed history was recorded and complete examination carried out. Relevant investigations were performed after obtaining informed consent.

\section{RESULTS}

Of a total of 200 patients aged above 60 years, maximum numbers of patients in this study belong to age group of 61 - 65 years ( $30 \%$ ) and the mean age in the study is 71.3 years.

- 129 males (64.5\%) and 71 females (35.5\%). Male-to-Female ratio was 1.81:1.

- 94 cases (47\%) had Associated Diseases. Diabetes Mellitus was the commonest associated disease (26.5\%).

- 60 patients had generalised pruritus, of which 42 cases (21\%) was associated with xerosis.

- Among the skin changes with aging wrinkling of the skin was seen in 184 cases (92\%), Xerosis in 108 cases (54\%), IGH in 60 cases (30\%), Senile Lentigines in 31 cases (15.5\%) and Senile Comedones in 15 cases $(7.5 \%)$.

- Among the pathological conditions, eczematous conditions were seen in 51 cases (25.5\%), commonest was exposure dermatitis seen in 10 cases (5\%), infections were seen in 65 cases (32.5\%) of which fungal infections was seen in 34 cases (17\%), bacterial infections was seen in 14 cases (7\%) and viral infections in 17 cases (8.5\%). Psoriasis was seen in 7 cases (3.5\%), Lichen planus in 3 cases $(1.5 \%)$ and 1 case $(0.5 \%)$ of Pityriasis rubra pilaris was seen. The most common benign skin tumour seen was Cherry angiomas $(105,52.5 \%)$. Among the malignant condition 2 cases each of Basal cell carcinoma and squamous cell carcinoma was seen, 8 cases of bullous disorders was seen out of which 4 cases (2\%) had Bullous Pemphigoid, 10 cases (5\%) of Psychocutaneous disorders was seen.

\section{CONCLUSION}

In our study, the commonest age group was 61 - 65 years. Majority of patients were males, majority of male patients were retired and majority of female patients were housewives. Diabetes mellitus was the commonest associated systemic disease. Generalised pruritus was most commonly associated with xerosis. Wrinkling was one of the commonest skin changes seen. Xerosis, senile lentigines, senile comedones, IGH were the other senile skin changes. Various pathological skin diseases like eczemas, infections, benign tumours, malignant tumours, Papulosquamous diseases, psychocutaneous diseases, vascular conditions, bullous disorders and drug reactions were seen.

\section{KEYWORDS}

Aging Skin, Geriatric.

HOW TO CITE THIS ARTICLE: Kumar SBC, Nayak KR. Clinical study of cutaneous manifestation of geriatric age group. J. Evolution Med. Dent. Sci. 2016;5(90):6707-6716, DOI: 10.14260/jemds/2016/1517

Financial or Other, Competing Interest: None.

Submission 10-08-2016, Peer Review 28-10-2016,

Acceptance 03-11-2016, Published 10-11-2016.

Corresponding Author:

Dr. Kavya Raju Nayak,

C/o. Shushrut Adigon,

\#434, DSR,

Rainbow Heights Apartment,

Sector 2, 24th Main,

HSR Layout-560102.

E-mail: drkavyanayak@gmail.com

DOI: $10.14260 /$ jemds/2016/1517

\section{BACKGROUND}

Aging is a complex process that is due to accumulation of molecular damage over time. ${ }^{1}$ Skin mirrors the first signs of natural aging, and the maintenance and improvement of its quality has gained particular attention.

Defining old - "Aging is a biological reality, which has its own dynamic beyond human control." People aged $60+$ years are generally referred to as older population. ${ }^{2}$ Aging is progressive, time dependent deterioration of an organism's structural or functional integrity and may be reflected in the ability of the organism to interact with and respond to its environment. 
Both intrinsic aging (Genetic, chronological aging) and extrinsic aging (Environmental, photoaging) contribute to cutaneous aging. ${ }^{3}$ Aging skin has susceptibility to dermatologic disorders due to the structural and physiological changes that occur as a consequence of intrinsic and extrinsic aging. 4

The common skin disorders prevalent in elderly are xerosis, pruritus, dermatoheliosis (Photoaging), benign tumours like acrochordons, seborrhoeic keratosis, cherry angioma, infections like herpes zoster, dermatophytosis, cellulitis, etc. Eczemas like asteatotic eczema, stasis eczema, discoid eczema and other forms of eczema are common in elderly. 3 These dermatoses are further complicated by increased frequency of chronic systemic diseases with increasing age.

With the improvement in socioeconomic conditions and major advances in medical field have led to significant increase in life expectancy. India being the second largest populated country in the world with 72 million elderly persons above 60 years of age as of 2001 and the number is likely to increase to 179 million in 2031 and further to 301 million in 2051. 4 The population is getting older with a greater percentage of population over 60 years. Hence, an increased emphasis on geriatric medicine is inevitable, geriatric dermatology is a specialty which requires special attention. With this background, the present study was undertaken to describe the frequency and clinical pattern of cutaneous manifestations in elderly population. The population aged above 60 years was considered for this study. ${ }^{2}$

\section{MATERIALS AND METHODS}

\section{Source of Data and Number}

- The study was carried on elderly, aged above 60 years attending Dermatology OPD as well as IPD at Kempegowda Institute of Medical Sciences, Bangalore.

- A total of 200 patients were included in the study.

\section{Inclusion Criteria}

- Patients aged above 60 years will be included in the study.

- $\quad$ Patient willing to give informed consent for taking part in the study.

\section{Exclusion Criteria}

- Onset of certain dermatological diseases before 60 years will not be included. Like patients with genodermatoses which interfere with aging skin, photosensitive genodermatoses, premature aging genodermatoses, albinos, inherited disorders of DNA instability were excluded.

\section{Method of Collection of Data}

a) A detailed history in all cases was taken,

- Name, age, sex, occupation, address.

- Chief complaints.

- Past history.

- Treatment and drug history.

- Family history.

- History of any allergy and personal history.

b) Complete general physical examination and systemic examination.

c) Thorough dermatological examination was carried out including the skin all over the body, hair, nails, oral and genital mucosa.

\section{Routine Investigations}

- Haemoglobin, Total Leukocyte count, Differential count.

- RBS.

- Urine routine.

\section{Other Tests}

ESR, liver function tests, blood urea, serum creatinine, lipid profile, serum electrolytes, thyroid profile and stool for occult blood (was done when required).

\section{Dermatological Procedures}

- Scrapings and nail clipping for fungal infection.

- Patch test, skin prick test.

- Skin biopsy.

- Pus for culture and sensitivity (was done when required).

\section{Statistics}

A total of 200 cases with age above 60 years attending OPD and IPD of Kempegowda Institute of Medical Sciences were included in the study.

\begin{tabular}{|c|c|c|}
\hline Age Groups & Number of Patients & Percentage (\%) \\
\hline $61-65$ & 60 & 30 \\
\hline $66-70$ & 55 & 28 \\
\hline $71-75$ & 40 & 20 \\
\hline $76-80$ & 24 & 12 \\
\hline $80+$ & 21 & 11 \\
\hline Grand Total & $\mathbf{2 0 0}$ & $\mathbf{1 0 0}$ \\
\hline \multicolumn{3}{|c|}{ Table 1. Age Distribution } \\
\hline
\end{tabular}

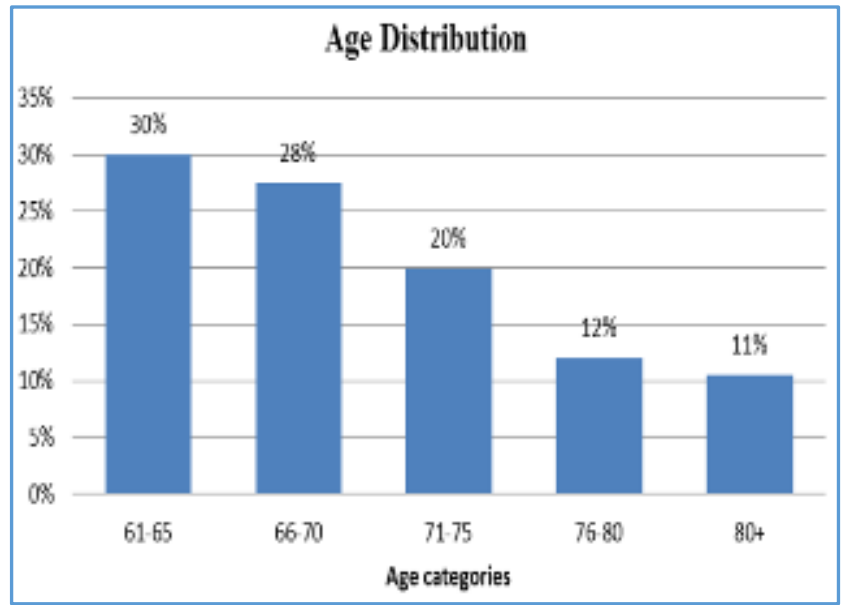

Figure 1. Age Distribution $(N=200)$

Maximum number of patients in this study belongs to age group of 61 - 65 years (30\%) followed by 66 - 70 years (28\%). The eldest patient was of 93 years and the mean age in the study is 71.3 years.

\begin{tabular}{|c|c|c|}
\hline Sex & Number of Patients & Percentage (\%) \\
\hline Female & 71 & 35.5 \\
\hline Male & 129 & 64.5 \\
\hline Grand Total & $\mathbf{2 0 0}$ & $\mathbf{1 0 0}$ \\
\hline \multicolumn{2}{|c|}{ Table 2. Sex Distribution (N = 200) } \\
\hline
\end{tabular}




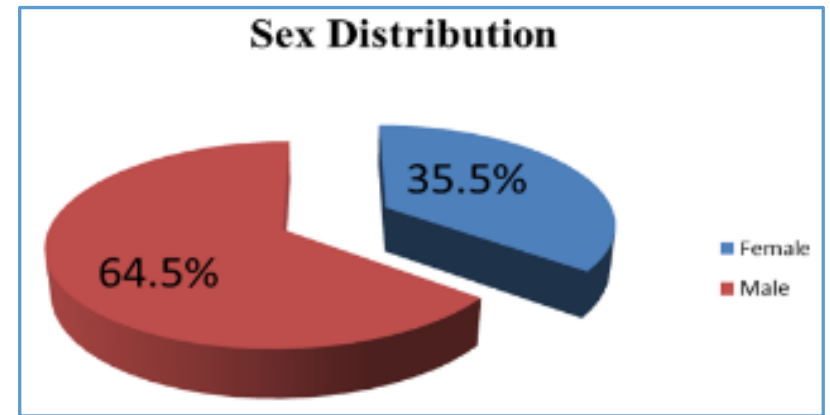

Figure 2. Sex Distribution

In this study of the 200 patients, there were 129 males (64.5\%) and 71 females (35.5\%). Male-to-Female ratio in the study was 1.81:1.

\begin{tabular}{|c|c|c|}
\hline Type & Number of Patients & Percentage \\
\hline Agricultural & 25 & 12.5 \\
\hline Housewives & 41 & 20.5 \\
\hline Retired & 108 & 54.0 \\
\hline Business & 26 & 13.0 \\
\hline \multicolumn{2}{|c|}{ Table 3. Occupation Distribution $(\mathbf{N}=\mathbf{2 0 0})$} \\
\hline
\end{tabular}

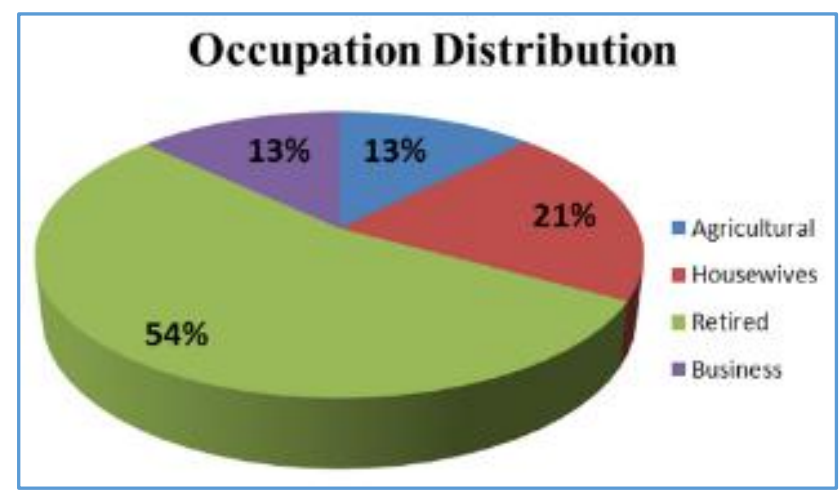

Figure 3. Occupation Distribution

\begin{tabular}{|c|c|c|c|}
\hline Type & Female & Male & Total \\
\hline Agricultural & 8 & 17 & 25 \\
\hline Housewives & 41 & & 41 \\
\hline Retired & 20 & 88 & 108 \\
\hline Business & 2 & 24 & 26 \\
\hline Total & $\mathbf{7 1}$ & $\mathbf{1 2 9}$ & $\mathbf{2 0 0}$ \\
\hline Table 4. Occupation Distribution by Gender $(\boldsymbol{N}=\mathbf{2 0 0})$ \\
\hline
\end{tabular}

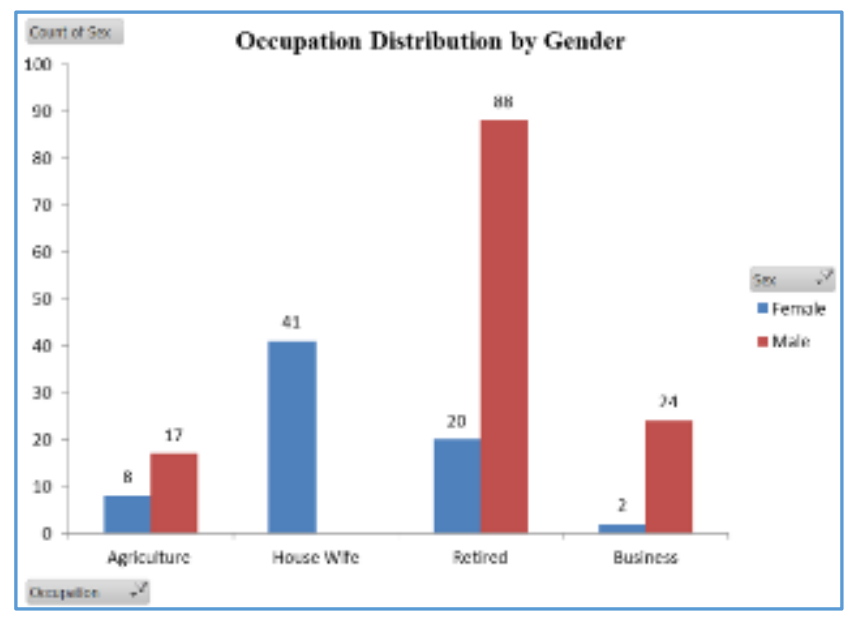

Figure 4. Occupation Distribution by Gender
In this study of the 200 patients, 108 were retired (54.0\%) of which 20 were females and 88 were males; $25(12.5 \%)$ were agriculturists of which 17 were males and 8 were females; 41 females were housewives (20.5\%); 26 (13\%) patients were doing some business of which 2 were females and 24 were males. Thus, most male patients were retired and most of the female patients were housewives.

\begin{tabular}{|c|c|c|}
\hline Associated Diseases & $\begin{array}{l}\text { No. of } \\
\text { Cases }\end{array}$ & Percentage (\%) \\
\hline Diabetes Mellitus & 53 & 26.5 \\
\hline Hypertension & 44 & 22.0 \\
\hline IHD & 9 & 4.5 \\
\hline Anaemia & 5 & 2.5 \\
\hline $\begin{array}{c}\text { Benign Prostatic } \\
\text { Hypertrophy }\end{array}$ & 4 & 2.0 \\
\hline Hypothyroidism & 3 & 1.5 \\
\hline Bronchial Asthma & 2 & 1.0 \\
\hline Alcoholic Liver Disease & 2 & 1.0 \\
\hline Carcinoma Cervix & 1 & 0.5 \\
\hline HIV & 1 & 0.5 \\
\hline Kidney Disease & 1 & $0.5 \%$ \\
\hline Rheumatoid Arthritis & 1 & $0.5 \%$ \\
\hline Peptic Ulcer & 1 & $0.5 \%$ \\
\hline COPD & 1 & $0.5 \%$ \\
\hline \multicolumn{3}{|c|}{ Table 5. Associated Diseases $(N=200)$} \\
\hline
\end{tabular}

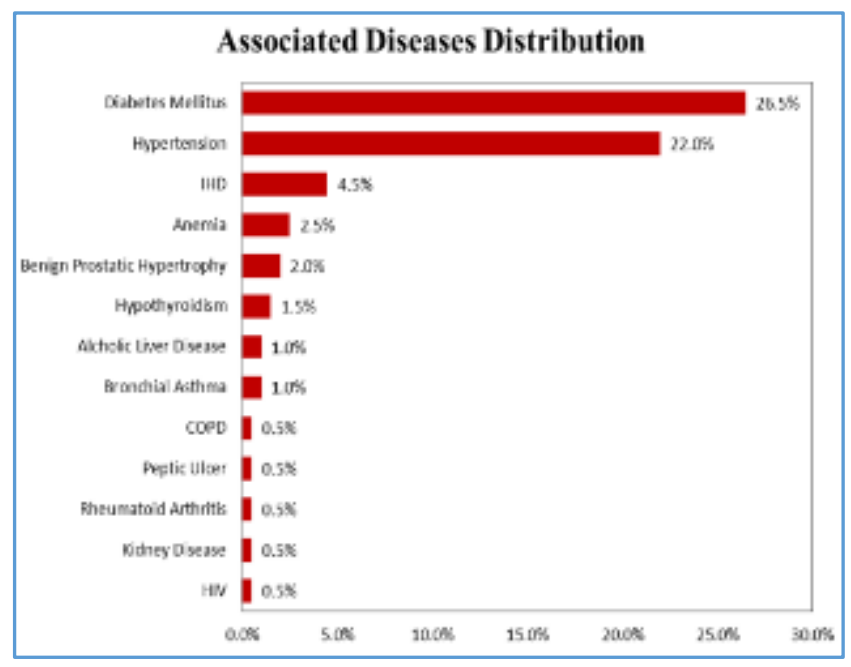

\section{Figure 5. Associated Disease Conditions $(N=200)$}

Diabetes Mellitus was the commonest associated disease seen in 53 cases (26.5\%) followed by Hypertension in 44 cases (22\%), IHD in 9 cases (4.5\%), Anaemia in 5 cases $(2.5 \%)$, Benign Prostatic Hypertrophy in 4 cases (2.0\%), Hypothyroidism in 3 cases (1.4\%), Bronchial Asthma in 2 cases (1.0\%), Alcoholic Liver Disease in 2 cases $(1 \%)$, Carcinoma Cervix in 1 case $(0.5 \%)$, HIV in 1 case $(0.5 \%)$, Kidney Disease in 1 case $(0.5 \%)$, Rheumatoid Arthritis in 1 case $(0.5 \%)$, Peptic Ulcer in 1 case $(0.5 \%)$ and COPD in 1 case $(0.5 \%)$. 


\begin{tabular}{|c|c|c|c|}
\hline No. & $\begin{array}{c}\text { Conditions } \\
\text { Associated with GP }\end{array}$ & $\begin{array}{c}\text { No. of } \\
\text { Cases }\end{array}$ & $\begin{array}{c}\text { Percentage } \\
\text { (\%) }\end{array}$ \\
\hline 1 & Xerosis & 42 & 21 \\
\hline 2 & Diabetes Mellitus & 14 & 7 \\
\hline 3 & Anaemia & 4 & 2 \\
\hline 4 & Hypothyroidism & 3 & 3 \\
\hline 5 & Alcoholic Liver Disease & 2 & 1 \\
\hline 6 & Kidney Disease & 1 & 0.5 \\
\hline 7 & HIV & 1 & 0.5 \\
\hline \multicolumn{3}{|c|}{ Table 6. Generalised Pruritus } \\
\hline
\end{tabular}

In this study generalised pruritus was seen in 60 cases (30\%), of which xerosis was associated with generalised pruritus in 42 cases (21\%), Diabetes Mellitus was associated in 14 cases (7\%), Anaemia in 4 cases (2\%), Hypothyroidism in $3(1.5 \%)$ cases, Alcoholic Liver Disease in 2 cases (1\%), HIV and Kidney disease in 1 case each $(0.5 \%)$. Thus, generalised pruritus was most commonly associated with xerosis in our study.

\begin{tabular}{|c|c|c|}
\hline Skin Changes & $\begin{array}{c}\text { Number of } \\
\text { Patients }\end{array}$ & $\begin{array}{c}\text { \% of Total } \\
\text { Patients }\end{array}$ \\
\hline Wrinkles & 184 & $92.0 \%$ \\
\hline Xerosis & 108 & $54.0 \%$ \\
\hline IGH & 60 & $30.0 \%$ \\
\hline Senile Lentigines & 31 & $15.5 \%$ \\
\hline Senile Comedones & 15 & $7.5 \%$ \\
\hline \multicolumn{2}{|c|}{ Table 7. Skin Changes with Aging (N= 200) } \\
\hline
\end{tabular}

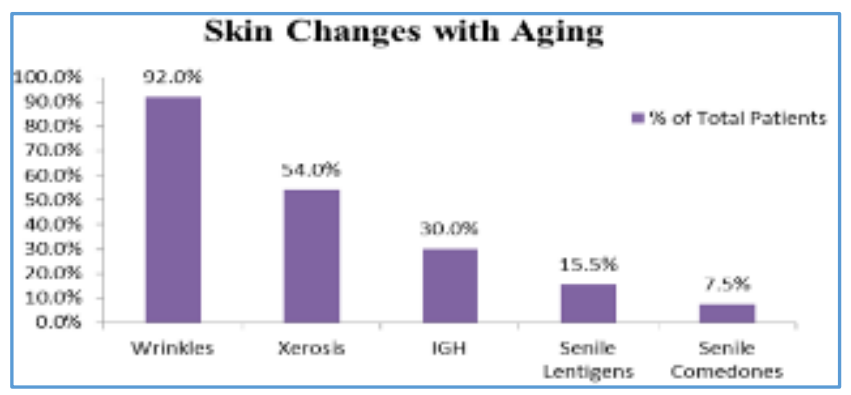

Figure 6. Skin Changes with Aging

In this study, wrinkling of the skin was one of the commonest finding and was seen in 184 cases (92\%). Xerosis was seen in 108 cases (54\%), IGH was seen in 60 cases (30\%), Senile Lentigines was seen in 31 cases $(15.5 \%)$ and Senile Comedones in 15 cases (7.5\%).

\section{Pathological Skin Changes}

\begin{tabular}{|c|c|c|}
\hline $\begin{array}{c}\text { Type of Eczematous } \\
\text { Conditions }\end{array}$ & $\begin{array}{c}\text { No. of } \\
\text { Cases }\end{array}$ & $\begin{array}{c}\text { Percentage } \\
\text { (\%) }\end{array}$ \\
\hline Exposure Dermatitis & 10 & 5.0 \\
\hline Chronic Eczema & 9 & 4.5 \\
\hline Contact Dermatitis & 7 & 3.5 \\
\hline Stasis Eczema & 6 & 3.0 \\
\hline $\begin{array}{c}\text { Infectious Eczematous } \\
\text { Dermatitis }\end{array}$ & 5 & 2.5 \\
\hline Asteatotic Eczema & 5 & 2.5 \\
\hline Seborrhoeic Dermatitis & 2 & 1.0 \\
\hline Nummular Eczema & 2 & $1.0 \%$ \\
\hline Hand Eczema & 2 & $1.0 \%$ \\
\hline Follicular Eczema & 2 & $1.0 \%$ \\
\hline Foot Eczema & 1 & $0.5 \%$ \\
\hline Grand Total & $\mathbf{5 1}$ & $\mathbf{2 5 . 5 \%}$ \\
\hline \multicolumn{2}{|c|}{ Table 8. Eczematous Conditions (N= 200) } \\
\hline
\end{tabular}

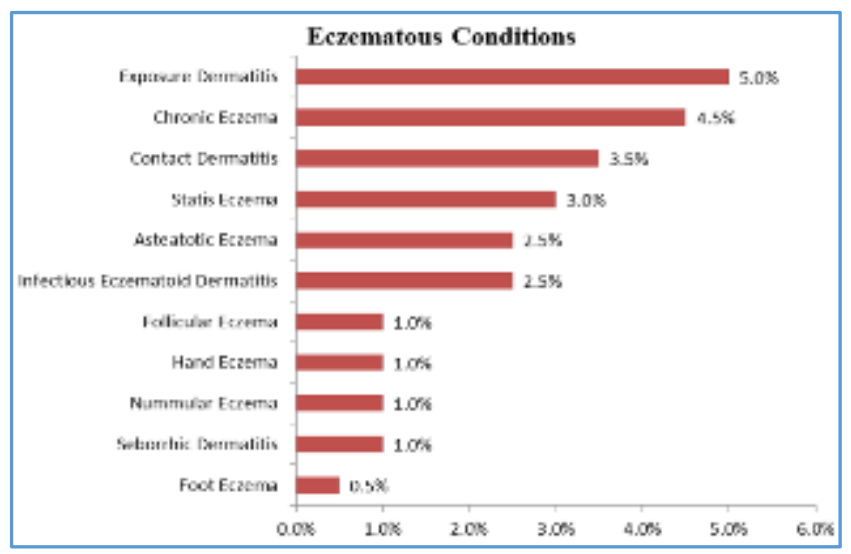

Figure 7. Eczematous Condition

In this study eczematous conditions were seen in 51 cases (25.5\%), commonest was exposure Dermatitis seen in 10 cases (5\%) followed by Chronic Eczema in 9 cases (4.5\%), Contact Dermatitis in 7 cases (3.5\%), Stasis Eczema in 6 cases (3\%), Infectious Eczematous Dermatitis in 5 cases $(2.5 \%)$ Asteatotic Eczema in 5 cases (2.5\%), 2 (1\%) cases each of Seborrhoeic Dermatitis, Nummular Eczema, Hand Eczema and Follicular Eczema; $1(0.5 \%)$ case of Foot Eczema was seen.

\begin{tabular}{|c|c|c|c|}
\hline $\begin{array}{c}\text { Type of } \\
\text { Infections }\end{array}$ & Sub-Type & $\begin{array}{l}\text { No. of } \\
\text { Cases }\end{array}$ & $\begin{array}{c}\text { Percentage } \\
\text { (\%) }\end{array}$ \\
\hline \multirow{3}{*}{$\begin{array}{l}\text { Fungal } \\
\text { Infections }\end{array}$} & Fungal Total & 34 & 17 \\
\hline & Dermatophytosis & 29 & 14.5 \\
\hline & Candidiasis & 5 & 2.5 \\
\hline \multirow{6}{*}{$\begin{array}{l}\text { Bacterial } \\
\text { Infections }\end{array}$} & Bacterial Total & 14 & 7.0 \\
\hline & Cellulitis & 6 & 3.0 \\
\hline & Leprosy & 3 & 1.5 \\
\hline & Furuncle & 2 & 1.0 \\
\hline & Folliculitis & 2 & 1.0 \\
\hline & Lupus Vulgaris & 1 & 0.5 \\
\hline \multirow{3}{*}{$\begin{array}{c}\text { Viral } \\
\text { Infections }\end{array}$} & Viral Total & 17 & 8.5 \\
\hline & Herpes Zoster & 13 & 6.5 \\
\hline & Viral Warts & 4 & 2.0 \\
\hline \multicolumn{2}{|c|}{ Grand Total } & 65 & 32.5 \\
\hline \multicolumn{4}{|c|}{ Table 9. Types of Infection } \\
\hline
\end{tabular}

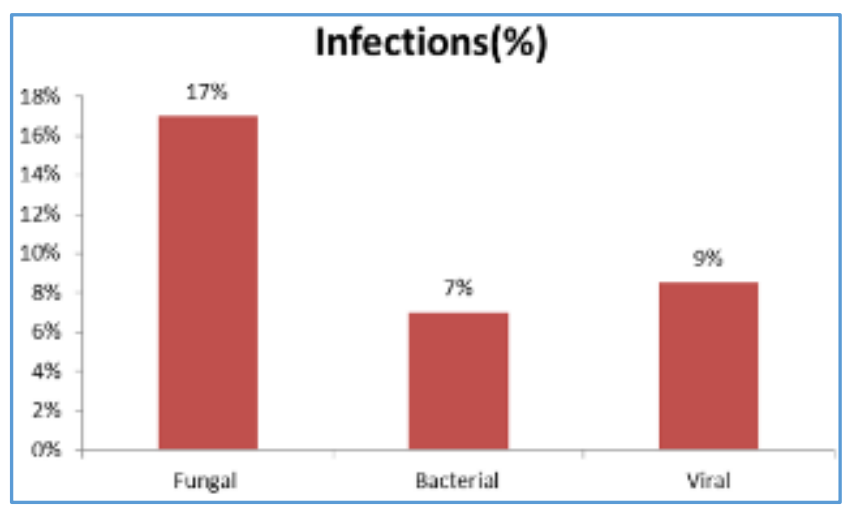

Figure 8. Types of Infection $(N=200)$

In this study infections were seen in 65 cases (32.5\%), of which fungal infections were seen in 34 cases (17\%), bacterial infections were seen in 14 cases $(7 \%)$ and viral infections in 17 cases $(8.5 \%)$. No infestations were seen. 
Of the 34 cases of fungal infections, Dermatophytosis was seen in 29 cases $(14.5 \%)$ and Candidiasis in 5 cases $(2.5 \%)$. Among the bacterial infections Cellulitis was seen in 6 cases (3\%), Leprosy in 3 cases (1.5\%), Furuncle in 2 cases $(1 \%)$, Folliculitis in 2 cases (1\%) and 1 case $(0.5 \%)$ of Lupus Vulgaris was seen. Among viral infections, Herpes zoster was seen in 13 cases $(6.5 \%)$ and viral warts in 4 cases (2\%).

\begin{tabular}{|c|c|c|}
\hline Types & No. of Cases & Percentage (\%) \\
\hline Psoriasis & 7 & 3.5 \\
\hline Lichen Planus & 3 & 1.5 \\
\hline Pityriasis Rubra Pilaris & 1 & 0.5 \\
\hline Grand Total & 11 & 5.5 \\
\hline \multicolumn{3}{|c|}{ Table 10. Papulosquamous Disorders $(N=200)$} \\
\hline
\end{tabular}

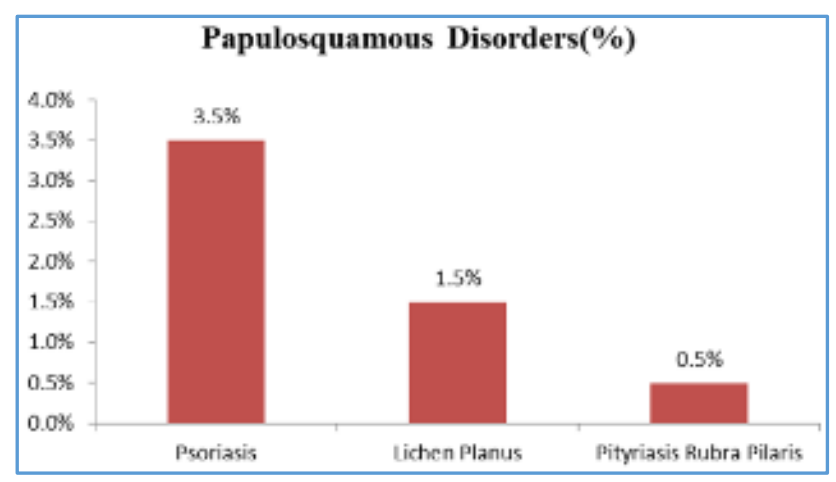

Figure 9. Papulosquamous Disorders

In this study Psoriasis was seen in 7 cases (3.5\%), Lichen planus in 3 cases $(1.5 \%)$ and 1 case $(0.5 \%)$ of Pityriasis rubra pilaris was seen.

\begin{tabular}{|c|c|c|c|}
\hline $\begin{array}{l}\text { No } \\
\text {. }\end{array}$ & Condition & $\begin{array}{l}\text { No. of } \\
\text { Cases }\end{array}$ & $\begin{array}{c}\text { Percentage } \\
(\%)\end{array}$ \\
\hline 1 & Cherry Angiomas & 105 & 52.5 \\
\hline 2 & Seborrhoeic Keratosis & 81 & 40.5 \\
\hline 3 & $\begin{array}{c}\text { Dermatosis Papulosa } \\
\text { Nigra }\end{array}$ & 72 & 36.0 \\
\hline 4 & Acrochordons & 50 & 25.0 \\
\hline 5 & Sebaceous Cysts & 1 & 0.5 \\
\hline 6 & $\begin{array}{l}\text { Angiokeratoma of } \\
\text { Fordyce }\end{array}$ & 1 & 0.5 \\
\hline 7 & Syringoma & 1 & 0.5 \\
\hline \multicolumn{4}{|c|}{ Table 11. Benign Tumours of Skin } \\
\hline
\end{tabular}

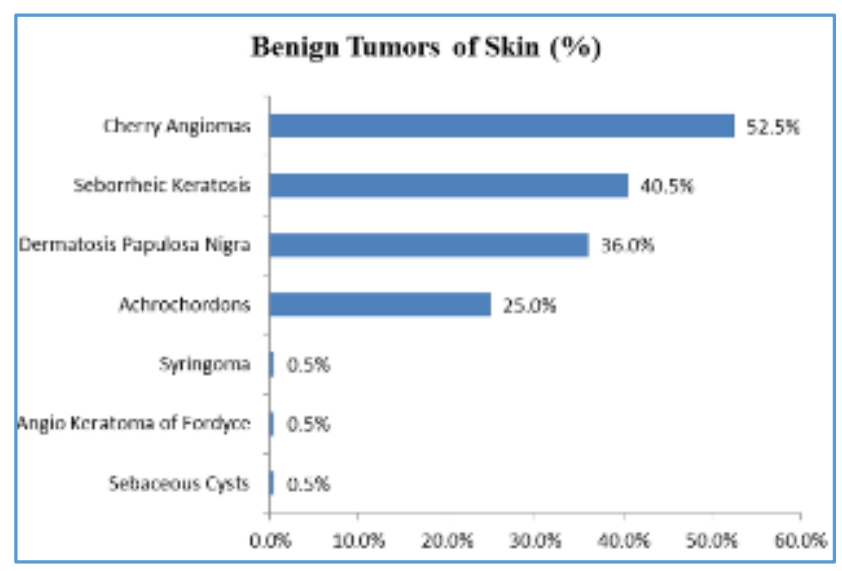

Figure 10. Benign Tumours of Skin
The most common benign skin tumour seen was Cherry angiomas $(105,52.5 \%)$ followed by Seborrhoeic Keratosis in 81 cases (40.5\%), Dermatosis Papulosa Nigra in 72 cases (36\%), acrochordons in $50(25 \%)$ cases, 1 case $(0.5 \%)$ each of Sebaceous cyst, Angiokeratoma of Fordyce and Syringoma.

\begin{tabular}{|c|c|c|c|}
\hline Types & Sub-Type & $\begin{array}{l}\text { No. of } \\
\text { Cases }\end{array}$ & $\begin{array}{c}\text { Percentage } \\
(\%)\end{array}$ \\
\hline $\begin{array}{c}\text { Pre- } \\
\text { Malignant } \\
\text { condition }\end{array}$ & Bowen's & 1 & 0.5 \\
\hline \multirow{2}{*}{$\begin{array}{c}\text { Malignant } \\
\text { Tumours }\end{array}$} & $\begin{array}{c}\text { Basal Cell } \\
\text { Carcinoma }\end{array}$ & 2 & 1 \\
\hline & $\begin{array}{l}\text { Squamous Cell } \\
\text { Carcinoma }\end{array}$ & 2 & 1 \\
\hline \multicolumn{2}{|c|}{ Grand Total } & 5 & 2.5 \\
\hline \multicolumn{4}{|c|}{ Table 12. Premalignant and Malignant Tumours } \\
\hline
\end{tabular}

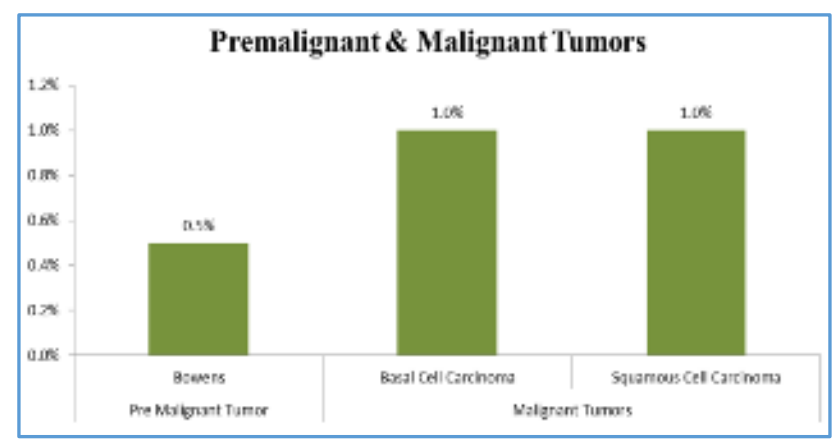

Figure 11. Premalignant \& Malignant Tumours $(N=200)$

In this study 1 case of premalignant tumours was seen, which was Bowen's disease. No actinic keratosis was seen. Among the malignant condition, 2 cases each of basal cell carcinoma and squamous cell carcinoma was seen. Of the two cases of squamous cell carcinoma, one case was cutaneous infiltration of squamous cell carcinoma with carcinoma cervix.

\begin{tabular}{|c|c|c|}
\hline Types & No. of Cases & Percentage (\%) \\
\hline Bullous Pemphigoid & 4 & $2.0 \%$ \\
\hline Pemphigus Vulgaris & 3 & $1.5 \%$ \\
\hline $\begin{array}{c}\text { Bullous Pyoderma } \\
\text { Gangrenosum }\end{array}$ & 1 & $0.5 \%$ \\
\hline Grand Total & $\mathbf{8}$ & $\mathbf{4 . 0 \%}$ \\
\hline \multicolumn{2}{|c|}{ Table 13. Bullous Disorders } \\
\hline
\end{tabular}

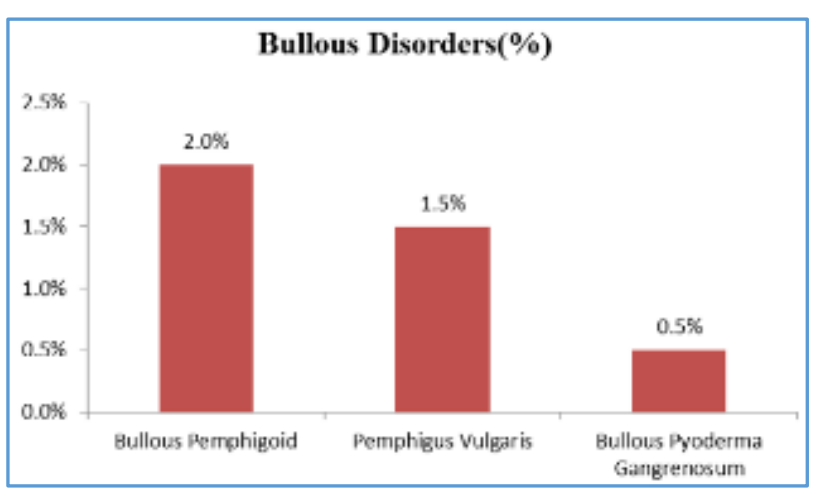

Figure 12. Bullous Disorders ( $=200)$

In this study 8 cases of bullous disorders was seen, out of which 4 cases $(2 \%)$ had Bullous Pemphigoid, 3 cases $(1.5 \%)$ 
had Pemphigus Vulgaris and 1 case of Bullous Pyoderma Gangrenosum was seen.

\begin{tabular}{|c|c|c|}
\hline Types & No. of Cases & Percentage (\%) \\
\hline $\begin{array}{c}\text { Lichen Simplex } \\
\text { Chronicus }\end{array}$ & 8 & $4.0 \%$ \\
\hline Prurigo Nodularis & 2 & $1.0 \%$ \\
\hline Grand Total & $\mathbf{1 0}$ & $\mathbf{5 . 0 \%}$ \\
\hline \multicolumn{2}{|c|}{ Table 14. Psychocutaneous Disorders } \\
\hline
\end{tabular}

In this study 10 cases of Psychocutaneous disorders was seen, of which 8 (4\%) cases had Lichen Simplex Chronicus and 2 (1\%) cases had Prurigo Nodularis.

\begin{tabular}{|c|c|c|c|}
\hline No. & Condition & $\begin{array}{c}\text { No. of } \\
\text { Cases }\end{array}$ & $\begin{array}{c}\text { Percentage } \\
\text { (\%) }\end{array}$ \\
\hline 1 & Senile Purpura & 4 & $2.0 \%$ \\
\hline 2 & $\begin{array}{c}\text { Pigmented Purpuric } \\
\text { Dermatoses }\end{array}$ & 1 & $0.5 \%$ \\
\hline \multicolumn{3}{|c|}{ Table 15. Vascular Disorders } \\
\hline
\end{tabular}

In this study, 4 cases (2\%) had senile purpura and $1(0.5 \%)$ case of pigmented purpuric dermatoses was seen.

\section{Drug Reactions in Elderly}

In this study out of the 200 cases 3 cases had drug reactions, 2 cases had Lichenoid Drug Eruptions and 1 case of drug reaction to Ciprofloxacin.

\begin{tabular}{|c|c|c|c|}
\hline No. & Condition & $\begin{array}{c}\text { No. of } \\
\text { Cases }\end{array}$ & $\begin{array}{c}\text { Percentage } \\
\text { (\%) }\end{array}$ \\
\hline 1 & Chronic Urticaria & 5 & $2.5 \%$ \\
\hline 2 & Colloid Milia & 4 & $2.0 \%$ \\
\hline 3 & Macular Amyloidosis & 2 & $1.0 \%$ \\
\hline 4 & $\begin{array}{c}\text { Lichen Sclerosus Et } \\
\text { Atrophicans }\end{array}$ & 2 & $1.0 \%$ \\
\hline 5 & Parapsoriasis & 2 & $0.5 \%$ \\
\hline 6 & $\begin{array}{c}\text { Reactive Perforating } \\
\text { Collagenosis }\end{array}$ & 1 & $0.5 \%$ \\
\hline 7 & Granuloma Annulare & 1 & $0.5 \%$ \\
\hline 8 & $\begin{array}{c}\text { Favre-Racouchot } \\
\text { Syndrome }\end{array}$ & 1 & $2 \%$ \\
\hline 9 & $\begin{array}{c}\text { Polymorphous Light } \\
\text { Eruptions }\end{array}$ & 1 & $0.5 \%$ \\
\hline 10 & Pruritus Ani & 1 & $0.5 \%$ \\
\hline 11 & Pyogenic Granuloma & 1 & $0.5 \%$ \\
\hline 12 & Lupus Profundus & 1 & $0.5 \%$ \\
\hline \multicolumn{3}{|c|}{ Table 16. Miscellaneous Conditions } \\
\hline
\end{tabular}

In this study Chronic Urticaria was seen in 5 cases (2.5\%), 2 cases (1\%) each of Colloid Milia in 4 cases (2\%). Parapsoriasis, Macular Amyloidosis and Lichen sclerosus et atrophicans was seen; 1 case (0.5\%) each of Favre-Racouchot Syndrome, reactive perforating collagenosis, granuloma annulare, polymorphous light eruption, Pruritus ani, Pyogenic Granuloma and Lupus Profundus were seen.

\begin{tabular}{|c|c|c|c|}
\hline No & Condition & $\begin{array}{l}\text { No. of } \\
\text { Cases }\end{array}$ & $\begin{array}{c}\text { Percentage } \\
\text { (\%) }\end{array}$ \\
\hline 1 & Loss of Luster & 110 & $55.0 \%$ \\
\hline 2 & Vertical Ridging & 101 & $50.5 \%$ \\
\hline 3 & Onychorrhexis & 60 & $30.0 \%$ \\
\hline 4 & Thickening & 36 & $18.0 \%$ \\
\hline 5 & Onychomycosis & 19 & $9.5 \%$ \\
\hline 6 & Thinning & 12 & $6.0 \%$ \\
\hline 7 & $\begin{array}{c}\text { Subungual } \\
\text { Hyperkeratosis }\end{array}$ & 10 & $5.0 \%$ \\
\hline 8 & Platyonychia & 10 & $5.0 \%$ \\
\hline 9 & Koilonychia & 6 & $3.0 \%$ \\
\hline 10 & Beau's Lines & 5 & $2.5 \%$ \\
\hline 11 & Pitting & 4 & $2.0 \%$ \\
\hline \multicolumn{4}{|c|}{ Table 17. Nail Changes in Elderly } \\
\hline
\end{tabular}

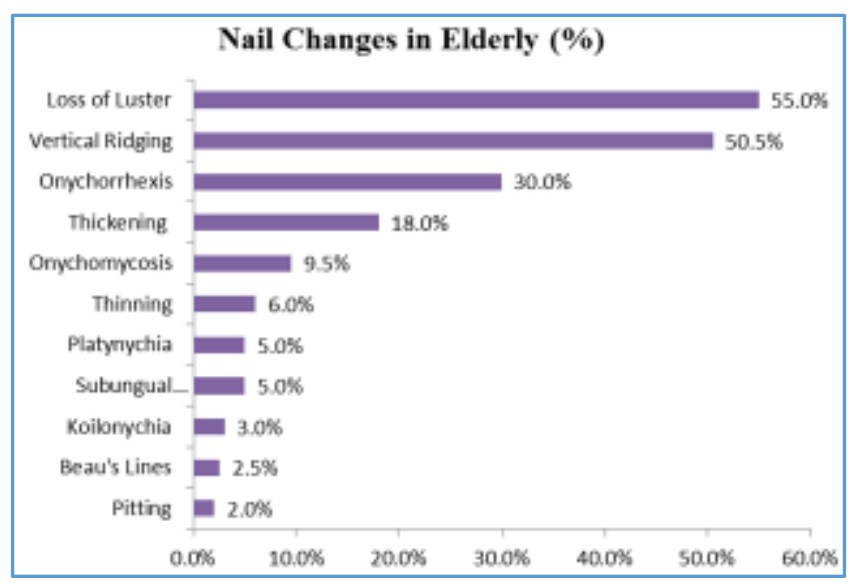

Figure 13. Nail Changes in Elderly $(N=200)$

In this study among the nail changes, loss of luster was the commonest followed by vertical ridging in 101 cases (50.5\%), Onychorrhexis in 60 cases (30\%), Onychomycosis in 38 cases (19\%), Thickening in 36 cases (19\%), Thinning in 12 cases (6\%), Subungual Hyperkeratosis in 10 cases (5\%), Platyonychia in 10 cases (5\%), Koilonychia in 6 cases (3\%), Beau's Lines in 5 cases ( 2.5\%) and Pitting in 4 cases (2\%).

\section{Hair Changes in Elderly}

In this study, greying of hair was one of the most common and was seen in 190 cases (95\%). Out of 71 female patients diffuse hair loss was seen in 51 females (71.8\%) and out of 129 males 81 (62.8\%) cases had Androgenic alopecia.

\begin{tabular}{|c|c|c|c|c|}
\hline No. & Condition & $\begin{array}{c}\text { No. of } \\
\text { Cases }\end{array}$ & $\begin{array}{c}\text { Males/ } \\
\text { Females }\end{array}$ & $\begin{array}{c}\text { Percentage } \\
\text { (\%) }\end{array}$ \\
\hline 1 & $\begin{array}{c}\text { Diffuse Hair Loss in } \\
\text { Females }\end{array}$ & 51 & 71 & $71.8 \%$ \\
\hline 2 & $\begin{array}{c}\text { Androgenic } \\
\text { Alopecia in Males }\end{array}$ & 81 & 129 & $62.8 \%$ \\
\hline \multicolumn{4}{|c|}{ Table 18 } \\
\hline
\end{tabular}

\section{RESULTS}

- In this study a total of 200 patients aged above 60 years attending the OPD and IPD of Kempegowda Institute of Medical Sciences were included. 
- Maximum number of patients in this study belong to age group of 61-65 years (30\%) followed by 66 - 70 years (28\%). The eldest patient was of 93 years and the mean age in the study is 71.3 years.

- In this study of the 200 patients, there were 129 males (64.5\%) and 71 females (35.5\%). Male-to-Female ratio in the study was 1.81:1.

- Most of the males were retired 108 cases (54\%) and most of the female patients were housewives.

- $\quad$ Out of 200 cases, 94 cases (47\%) had Associated Diseases. Diabetes Mellitus was the commonest associated disease seen in 53 cases (26.5\%) followed by Hypertension in 44 cases $(22 \%)$,

- 60 patients had generalised pruritus, of which 42 cases (21\%) was associated with xerosis.

- Wrinkling of the skin was one of the commonest finding and was seen in 184 cases (92\%). Xerosis was seen in 108 cases $(54 \%)$, IGH was seen in 60 cases $(30 \%)$, Senile Lentigines was seen in 31 cases (15.5\%) and Senile Comedones in 15 cases (7.5\%).

- Among the pathological conditions, eczematous conditions were seen in 51 cases $(25.5 \%)$, commonest was exposure dermatitis seen in 10 cases (5\%).

- In this study infections were seen in 65 cases (32.5\%), of which fungal infections was seen in 34 cases $(17 \%)$, bacterial infections was seen in 14 cases $(7 \%)$ and viral infections in 17 cases (8.5\%). No infestations were seen. Of the 34 cases of fungal infections, dermatophytosis was seen in 29 cases $(14.5 \%)$ and Candidiasis in 5 cases (2.5\%). Among the bacterial infections Cellulitis was seen in 6 cases (3\%), Leprosy in 3 cases $(1.5 \%)$, Furuncle in 2 cases $(1 \%)$, Folliculitis in 2 cases (1\%) and 1 case $(0.5 \%)$ of lupus vulgaris was seen. Among viral infections, Herpes zoster was seen in 13 cases (6.5\%) and viral warts in 4 cases $(2 \%)$.

- In this study Psoriasis was seen in 7 cases (3.5\%), Lichen planus in 3 cases $(1.5 \%)$ and 1 case $(0.5 \%)$ of Pityriasis rubra pilaris was seen.

- The most common benign skin tumour seen was Cherry angiomas $(105,52.5 \%)$ followed by Seborrhoeic Keratosis in 81 cases (40.5\%), Dermatosis Papulosa Nigra in 72 cases (36\%), acrochordons in $50(25 \%)$ cases, 1 case $(0.5 \%)$ each of Sebaceous cyst, Angiokeratoma of Fordyce and Syringoma.

- In this study 1 case of premalignant tumours were seen, which was Bowen's disease. No actinic keratosis was seen. Among the malignant condition, 2 cases each of basal cell carcinoma and squamous cell carcinoma was seen.

- In this study 8 cases of bullous disorders was seen, out of which 4 cases (2\%) had Bullous Pemphigoid, 3 cases (1.5\%) had Pemphigus Vulgaris and 1 case of Bullous Pyoderma Gangrenosum was seen.

- In this study 10 cases of Psychocutaneous disorders was seen, of which 8 (4\%) cases had Lichen Simplex Chronicus and $2(1 \%)$ cases had Prurigo Nodularis.

- In this study, 4 cases (2\%) had senile purpura and 1 (0.5\%) case of pigmented purpuric dermatoses was seen.

- Three cases of drug reactions was seen, of which 2 had lichenoid drug eruption and 1 had drug reaction to ciprofloxacin.
- In this study, Chronic Urticaria was seen in 5 cases (2.5\%); 2 cases $(1 \%)$ each of Parapsoriasis, Macular Amyloidosis and Lichen sclerosus et atrophicans was seen; 1 case $(0.5 \%)$ each of Favre-Racouchot Syndrome, reactive perforating collagenosis, Granuloma annulare, Colloid milia, polymorphous light eruption, Pruritus ani, Pyogenic Granuloma and Lupus Profundus were seen.

- In this study, among the nail changes loss of luster was the commonest followed by vertical ridging in 101 cases (50.5\%).

- In this study, greying of hair was one of the most common and was seen in 190 cases (95\%). Out of 71 female patients, diffuse hair loss was seen in 51 females $(71.8 \%)$ and out of 129 males, 81 (62.8\%) cases had Androgenic alopecia.

\section{DISCUSSION}

Aging is progressive, time dependent deterioration of an organism's structural or functional integrity and may be reflected in the ability of the organism to interact with and respond to its environment. Both intrinsic aging (Genetic, chronological aging) and extrinsic aging (environmental, photoaging) contribute to cutaneous aging. ${ }^{3}$ Aging skin has susceptibility to dermatologic disorders due to the structural and physiological changes that occur as a consequence of intrinsic and extrinsic aging. ${ }^{4}$

\section{Number of Cases in Relation to Age and Sex}

In this study, a total of 200 patients varying in age from 61 - 93 years were examined. Of these, 129 patients (64.5\%) were males and 71 (35.5\%) were females. The eldest patient was 93 years of age. Mean age was 71.35 years.

Droller made a study on random cases of 476 individuals in their homes. Out of this 192 were men and 284 were women; all patients between 60 to 90 years of age. 5 Tindall and Smith $^{6}$ studied 163 volunteers in their homes, all above 64 years of age. Verbov 7 examined 170 consecutive patients aged 60 to 90 years in an OPD. Weismann et al ${ }^{8}$ studied 494 residents of a Danish home for the aged between 55 and 106 yrs. of age. Beauregard and Gilchrest ${ }^{9}$ studied 68 patients aged between 50 - 91 years, recruited from 11 subsidised housing projects, of which $88.2 \%$ were females. Patange and Fernandez ${ }^{10}$ studied 200 cases in an ODP setting, aged 55 - 85 years of age, out of which $63 \%$ were males and $37 \%$ were females. In this study, males outnumber females by 5.31:1. Priya Cinna and Thappa did a hospital-based descriptive study on 500 elderly females aged 50 years and above and males aged 60 years and above. ${ }^{11}$ In their study, female-to-male ratio was $1.34: 1$. Out of 500,213 were males (42.6\%) and 287 (57.4) were females.

\section{Associated Conditions}

In this study, 94 patients (47\%) had associated systemic illnesses. Some patients had more than one systemic illness. Diabetes mellitus was the commonest association seen in 53 cases (26.5\%) followed by hypertension (22\%).

In a study by Priya Cinna and Thappa, Diabetes (28.9\%) and Hypertension (25.5\%) were the commonest associated condition, ${ }^{11}$ which was similar to our study. Beauregard and Gilchrest described $89.7 \%$ of patients to have major medical illnesses, of which $88.2 \%$ were on medication. Patange and Fernandez observed associated systemic ailments in $30 \%$ of cases. ${ }^{11}$ 


\section{Symptomatology}

In our study generalised pruritus was seen in 60 cases (30\%), of which xerosis was associated with generalised pruritus in 42 cases (21\%), Diabetes Mellitus was associated in 14 cases (7\%), Anaemia in 4 cases (2\%), Hypothyroidism in $3(1.5 \%)$ cases, Alcoholic Liver Disease in 2 cases (1\%), HIV and Kidney disease in 1 case each $(0.5 \%)$. Thus, generalised pruritus was most commonly associated with xerosis in our study.

Droller does not mention complaints of patients separately, but noticed generalised pruritus in $29.7 \%$ males and $29.2 \%$ females. ${ }^{6}$ Beauregard and Gilchrest[12] found skin complaints in $66.2 \%$ patients. Pruritus was the commonest, seen in $29 \%$. Patange and Fernandez ${ }^{11]}$ observed pruritus in $78.5 \%$ patients. Out of this $91 \%$ were associated with cutaneous dermatoses, $5.1 \%$ with systemic disorders and $3.8 \%$ were cases of senile pruritus without underlying skin or systemic disease. The incidence of pruritus in this study [79.2\%] is comparable to that seen by Patange and Fernandez [78.5\%].

\section{Skin Changes with Aging}

With ageing, there are so many cutaneous changes that it becomes difficult to delineate physiological from the pathological. Intrinsic physiologic changes in the epidermis, dermis, vasculature and skin appendages by themselves cause most of the changes. In this study, the following have been considered physiological changes: Wrinkling, atrophy of skin, xerosis, senile lentigines, idiopathic guttate hypomelanosis and dermatoheliosis - a combination of skin changes due to actinic damage.

a) Wrinkling - This was a common finding in the study and noticed in 184 patients [92\%]. This is comparable with the findings of Grover and Narasimhalu [191 (95.5\%)].13 Priya Cinna and Thappa found in $100 \%$, Tindall and Smith [94\%] and Beauregard and Gilchrest [95.6\%]. Patange and Fernandez do not mention the incidence of wrinkling. ${ }^{11}$ Most of the wrinkling seen in this study was on sun exposed areas like the face, neck, forearms and dorsa of hands.

b) Xerosis - Xerosis literally means dry skin. When associated with eczematous changes, it is called asteatotic eczema. In this study, Xerosis was seen in 108 patients [54\%]. Tindall and Smith $^{7}$ reported an incidence of xerosis in $77 \%$, while Beauregard and Gilchrest found it to be $85 \%$ of patients. Patange and Fernandez ${ }^{11}$ have reported this finding in 9\%. Chopra et al found in 108 (50.8\%) cases. ${ }^{14}$ Our study shows similar results as that seen by Chopra et al, but lower incidence of xerosis in this study as compared to those by Tindall and Smith and Beauregard and Gilchrest could be attributed to the tropical climate in which the patients of this study live and relative humidity in tropical climates is more than that in temperate climates reducing the degree of xerosis.

c) Senile Lentigines - The incidence of senile lentigines in this study was found in 31 cases [16.5\%]. Tindall Smith ${ }^{7}$ reported an incidence of $51 \%$. Beauregard and Gilchrest 10 reported senile lentigines in $70.6 \%$. Patange and Fernandez ${ }^{11}$ found an incidence of $12 \%$. The incidence of senile lentigines in this study is comparable to that of Patange and Fernandez, which was carried out on a similar ethnic population. Racial influence on colour of skin could be the cause for lesser incidence of senile lentigines seen in our Indian population as compared to the Western fair skinned individuals, who are more prone to senile lentigines.

d) Idiopathic Guttate Hypomelanosis - Idiopathic guttate hypomelanosis in our study was seen in 30\% [60 cases]. This finding was similar to that observed by Priya Cinna and Thappa 26\% (130),12 Beauregard and Gilchrest 10 reported an incidence of $24.4 \%$ and Patange and Fernandez found it in $24.5 \%$ (49). Most lesions were seen in sun protected areas of skin.

e) Senile Comedones - Dermatoheliosis is a combination of skin changes produced by solar damage and consists of senile comedones, irregular pigmentation, wrinkling, scaling actinic keratoses, elastosis and malignancy. Senile comedones commonly represent solar damage and in this study they represent dermatoheliosis. An incidence of 15 cases [7.5\%] of senile comedones (represented by dermatoheliosis) was found in this study, which was comparable to that observed by Grover and Narasimhalu ${ }^{13}(13,6.5 \%)$ and in study by Priya Cinna and Thappa observed in 23 (4.6\%) individuals. The sites where signs of senile comedones was seen were periorbital, medial infraorbital regions, cheeks, nose and forehead.

Pathological Skin Changes - Among the various pathologic skin changes seen in the elderly in this study, the following conditions are discussed:- Papulosquamous disorders, eczematous conditions, infections and infestations, pigmentary disorders, benign skin tumours, premalignant and malignant skin tumours, vascular disorders, bullous disorders, psychocutaneous disorders and miscellaneous skin changes.

a) Papulosquamous Disorders - In this study, psoriasis was seen in 7 cases [3.5\%]. Tindall and Smith found psoriasis in $1 \%$ of cases. Beauregard and Gilchrest 10 mention an incidence of $2.9 \%$, while Patange and Fernandez ${ }^{11}$ found it in $10.5 \%$. This study compares well with that of Beauregard and Gilchrest.

An incidence of 3 cases [1.5\%] of lichen planus and cases of lichenoid drug eruptions was also seen in this study. Other studies have not mentioned this condition.

One case of Pityriasis Rubra Pilaris was seen [0.5\%].

b) Eczematous Conditions - In our study, eczema was found in 50 cases (25\%). Contact Dermatitis was found in 7 cases $(3.5 \%)$, exposure dermatitis in 10 cases $(5 \%)$, stasis eczema in 6 cases (3\%), seborrhoeic dermatitis in 6 cases (3\%), asteatotic eczema in 5 cases $(2.5 \%)$ and infective eczematous dermatitis in 5 cases $(2.5 \%)$.

Priya Cinna and Thappa found an incidence of eczema in $24.2 \%$ (121) similar to that seen in our study. Verbov reported an incidence of $24.7 \%$ with $10 \%$ having allergic contact dermatitis. Weismann ${ }^{9}$ reported seborrhoeic dermatitis in 7\%, stasis dermatitis in $6.9 \%$ and contact dermatitis in $3.8 \%$.

Johnson reported seborrhoeic dermatitis in 3.6\%, contact dermatitis in $2 \%$ and eczema in $1.8 \%$. Beauregard and Gilchrest reported contact dermatitis in $11.8 \%$, seborrhoeic dermatitis in $10.5 \%$ and stasis dermatitis in $5.9 \%$. Patange and Fernandez ${ }^{11}$ found contact dermatitis in $7.5 \%$ and lichen simplex chronicus in $12 \%$.

The incidence of contact dermatitis compares well with that of Weismann. While the incidence of seborrhoeic dermatitis compares well with the findings of Johnson. And 
incidence of stasis eczema was similar to that of Beauregard and Gilchrest.

c) Infective Conditions and Infestations - In this study infective conditions were seen in 62 (31\%) cases, fungal infections was seen in $34(17 \%)$ cases, viral infections in 17 (8.5\%) cases and bacterial infections in 14 (7\%).

Dermatophytosis was seen in 29 cases (14.5\%), Candidal infections in 5 cases (2.5\%). Among bacterial infections 3 cases of leprosy, 2 cases of furuncle, 2 cases of bacterial folliculitis and 6 cases of cellulitis was seen. Among viral infections, 13 (6.5\%) cases of Herpes Zoster of which 7 had post-herpetic neuralgia and $4(2 \%)$ cases of viral warts were seen.

Tindall and Smith7 reported dermatophytosis in 79\%, but not the incidence of other infections. Johnson reported an incidence of $12.7 \%$ for dermatophytoses. Beauregard and Gilchrest found dermatophytoses in $17.7 \%$. Patange and Fernandez reported infective dermatoses as $34.5 \%$ of the total dermatoses. Out of this, fungal infection was found in $17.5 \%$, bacterial infection in $8.5 \%$ and viral infections in $5 \%$. Priya Cinna and Thappa found infectious conditions in $46.8 \%$, of which fungal infections were the commonest (34.4\%), onychomycosis in $22.2 \%$, bacterial infections in $0.8 \%$ and viral infections in $0.6 \%$.

The incidence of infective conditions in our study compares well with the observations of Patange and Fernandez, the incidence of dermatophyte infections in our study is similar to that seen by Beauregard and Gilchrest and by Patange and Fernandez.

d) Benign Tumours of the Skin - In our study, seborrhoeic keratosis was seen in $81(40.5 \%)$ cases. Cherry angiomas was seen in 105 (52.5\%) cases, Dermatoses papulosa nigra was seen in 72 cases (36\%), Acrochordons was seen in 50 cases $(25 \%)$.

Priya Cinna and Thappa found seborrhoeic keratosis in $253(50.6 \%)$ cases and Cherry angioma in 36 (7.2\%) cases and acrochordons in 49\%. Grover and Narasimhalu found Seborrhoeic Keratosis in 43\% and Cherry angioma in 63\%.

Tindall and Smith found seborrhoeic keratoses in $88 \%$ of cases and cherry angiomas in $75 \%$ of cases. Beauregard and Gilchrest ${ }^{10}$ observed seborrhoeic keratoses in $61.2 \%$ and cherry angiomas in 53.7 cases. They also report 58.8\% incidence of dermatosis papulosa nigra. Plantae found Cherry angioma in $46.5 \%$ seborrhoeic keratoses in $37.5 \%$, melanocytic nevi in $32.5 \%$ and acrochordons in $24.5 \%$ of cases.

The findings in this study are comparable with that of Beauregard and Gilchrest for cherry angioma. Finding of seborrhoeic keratosis in this study compares well with that of Grover and Narasimhalu and that of acrochordons is similar to that observed by Patange.

e) Premalignant and Malignant Tumours - One case of Bowen's disease were seen in the study. Actinic keratosis was not observed in our study. Actinic keratosis has been frequently reported in studies done in Western countries. Beauregard et al study, the percentage of actinic keratosis was $17.7 \%$ and that by Cvitanovic ${ }^{15}$ et al was $22.38 \%$. Priya Cinna and Thappa did not observe actinic keratosis in their study similar to our study. In our study actinic keratosis was not observed because of skin type IV/V, which is photoprotective; $4(2 \%)$ malignant tumours were encountered in our study, of which 2 were
Squamous cell carcinoma and 2 were Basal cell carcinoma.

Priya Cinna and Thappa reported 5 cases of malignancy (1\%). Patange has reported no case of skin malignancy. The lower incidence of premalignant and malignant skin tumours in this study could be because of the lower incidence of skin cancer in racially pigmented skin, which was found in our study population. Higher incidence was seen by Verbov, found an incidence of $13.5 \%$ for malignant skin tumours; Beauregard and Gilchrest have reported actinic keratoses in $17.7 \%$ and skin cancer in $4.4 \%$.

f) Vascular Disorders - In this study, senile purpura was seen in 4 cases $(2 \%)$ and pigmented purpuric dermatoses in 1 case $(0.5 \%)$.

Tindall and Smith have reported pigmented purpuric dermatoses in $31 \%$ of cases. Beauregard and Gilchrest ${ }^{10}$ observed senile purpura in $11.9 \%$, while Patange and Fernandez found an incidence of $9 \%$ of senile purpura. Thus, occurrence of senile purpura and pigmented purpuric dermatoses in the present study in much lower than that observed by others. The lower incidence of purpuric dermatoses and purpura in this study could be due to the difficulty in spotting purpuric changes in the racially pigmented skin of our study population.

g) Bullous Disorders - Among the various bullous disorders, only 4 cases of bullous pemphigoid (2\%) and 3 cases of pemphigus vulgaris $(1.5 \%)$ was seen. One case of Bullous Pyoderma Gangrenosum.

Priya Cinna and Thappa ${ }^{12}$ found Pemphigus vulgaris in 9 cases $(1.8 \%)$ and Bullous Pemphigoid in 8 cases $(1.6 \%)$; findings were similar to that seen in our study.

h) Psychocutaneous Dermatoses - In our study 10 (5\%) cases of psychocutaneous dermatoses was observed, of which $8(4 \%)$ cases had Lichen simplex chronicus and 2 $(1 \%)$ cases had prurigo nodularis.

i) Miscellaneous Skin Conditions - In this study, Chronic Urticaria was seen in 5 cases (2.5\%); 2 cases (1\%) each of Parapsoriasis, Macular Amyloidosis and Lichen sclerosus et atrophicans was seen; 1 case $(0.5 \%)$ each of FavreRacouchot Syndrome, reactive perforating collagenosis, granuloma annulare, colloid milia, polymorphous light eruption, pruritus ani, pyogenic granuloma and lupus profundus were seen. Other studies do not mention their incidences.

\section{Hair Changes}

Greying of hair was almost universal and seen in 190 cases (95\%). Hair loss in elderly women in our study was mostly diffuse thinning of hair, was seen in $72 \%$ (114 cases) and androgenic alopecia in males was noticed in 125 cases (62.5\%).

In study by Priya Cinna and Thappa, ${ }^{12}$ greying was seen in 97.2\% males and 90.9\% females. Diffuse hair thinning was seen in $67.24 \%$ males and androgenic alopecia was seen in $55.39 \%$ males. Pantage observed male pattern baldness in 20 males and diffuse hair loss in 94 females in their study of 200 patients.

\section{Nail Changes}

In our study loss of luster was the commonest finding seen in 110 cases (55\%), vertical ridgings was seen in 101 cases 
(50.5\%) and was the second common nail change. Onychomycosis was seen in 38 cases (19\%).

Priya Cinna and Thappa ${ }^{12}$ found that loss of luster was the commonest nail change seen in $50.8 \%$, vertical ridging was seen in $24 \%$ and onychomycosis in $22.5 \%$. Pantage and Fernandez observed loss of luster in $20.5 \%$. Grover and Narasimhalu 13 observed loss of luster in $64 \%$, vertical riding in $72.5 \%$ and onychomycosis in $12 \%$.

The findings of loss of luster of nails compares well with that of Priya Cinna and Thappa. Finding of Onychomycosis compares well with Grover and Narasimhalu.

\section{REFERENCES}

1. Millington GMV, Graham-Brown RAC. Skin and skin diseases throughout life. In: Burns T, Breathnach S, Cox N. eds. Rook's Textbook of Dermatology. $8^{\text {th }}$ edn. Oxford: Wiley Blackwell Publication 2010;8:21-9.

2. World Health Organisation. Definition of elderly person. www.who.int/healthinfo/survey/ageingdefinition/older/ en/index.html.

3. Fenske NA, Lober CW. Aging and its effects on skin. In: Moschella SL, Hurley HJ. eds. Dermatology. $3^{\text {rd }}$ edn. Philadelphia: WB Sauders 1992:107-22.

4. Rajan SI, Sarma PS, Mishra US. Demography of Indian Aging, 2001-2051. J Aging Soc Policy 2003;15(2-3):11-30.

5. Verma SB, Wollina U. Callosities of cross legged sitting "Yoga sign" an under recognized cultural cutaneous presentation. Int J Dermatology 2008;47(11):1212-4.
6. Tindall JP, Smith G. Skin lesions of the aged and their association with internal changes. JAMA 1963;186:103942.

7. Doller H. Dermatologic findings in random sample of old persons. Geriatric 1955;10(9):421-4.

8. Verbov J. Skin problems in The older patients. Practitioner 1975;215(1289):612-22.

9. Beauregard S, Gilchrest BA. A survey of skin problems and skin care regemens in elderly. Arch Dermatology 1987;123(12):1638-43.

10. Patange VS, Fernandez RJ. A study of geriatric dermatoses. Indian J Dermatology Venerol Leprol 1995;61(4):206-8.

11. Durai PC, Thappa DM, Kumari R. Aging in elderly: chronological versus photoaging. Indian J Dermatol 2012;57(5):343-52.

12. Jafferany M, Huynh TV, Silverman MA, et al. Geriatric dermatoses: a clinical review of skin diseases in an aging population. Int J of Dermatology 2012;51(5): 509-22.

13. Grover S, Narasimhalu CRV. A clinical study of skin changes in Geriatric population. Indian J of Dermatol Venerol and Leprol 2009;75(3):305-6.

14. Chopra A, Kullar J, Chopra D, et al. Cutaneous physiological and pathological changes in elderly. Indian J of Dermatol Venerol and Leprol 2000;66(5):274.

15. Cvitanovi H, Eva EK, Kuljanac I. Skin diseases in geriatric patients group. Coll Antropol 2010;(Suppl 34):247-51. 